\title{
A Sociological Perspective on the Issue of Killing In The Name of Honor in Pakistan
}

\author{
Dr. Memoona Saeed Lodhi ${ }^{1} \&$ Dr. Jawaid Ahmed Siddiqui ${ }^{2}$ \\ 1 Assistant Professor \& 2 Dean \\ Faculty of Humanities and Social Sciences, Hamdard University Karachi, Pakistan
}

\begin{abstract}
The traditionally dominated societies have always captivated human mind to think and act within cultural boundary. The world is moving ahead yet the society is reversing back to the traditional mindset. It has hampered rational thinking, while promoting violent acts- together breach humanity. The International forum as well as Islamic laws has always been supportive to the rights of others, mainly the status of women is supported through laws, conventions and treaties; but few of the societies have been ignorant to the dignity of women. This research article reflects the issue of honor killing in Pakistan. Within qualitative research methodology, historical method of research has been used for this study. The data is collected using authentic literature and previous researches. The results gathered show that due to weak governance, lack of implementation of proper laws, and due to social and cultural barriers, women are subjected to violence not only in Pakistan but also across the world. People are so attached to the practice of traditional and cultural values that it has increased violence against women. The cases of honor killing are escalating due to ignorance. Although women are empowered in Pakistan, yet their status is not completely functional. The results suggest passing strict laws against the crime of honor killing. Societal awareness is very important to eradicate ignorance from the society. Women should be empowered to take such issues seriously and fight back for their rights.

Keywords: Honor Killing, Sociological Perspective, Pakistan
\end{abstract}

\section{Introduction}

Cultural and traditional values are considered as the asset of every society. All the acts and deeds of human are often directed by the laws, locally set by forefathers. These laws are so well established that human cannot assume thinking out of the box. If the action is taken against the laws or if any act is performed which is unacceptable, severe punishment is verdict for the rule breaker. Few of the traditional laws and rituals are morally and philosophically acceptable, while the others are outdated and irrational to practice these days, yet society cannot rationalize it due to ignorance and cultural dominance. Since there are many transitions taking place in the world (Swadzba, 2011) and the level of awareness and knowledge is improving, it is expected that modern values would have overcome the traditional values; however, the reality is quiet opposite. In few of the societies, traditional practices are still functional, but since there are no defined cultural and traditional standards, they serve as a threat to the progress of humanity.

From the sociological point of view, few of the philosophers support cultural changes and believe that the changes are taking place in the world due to economic progress and modernization; however, other philosophers claim that culture has autonomous impact on the world and people remain static to its practice in all the circumstances. Due to religious integration, few of the cultural values are so strongly dominated that even modernization cannot change its practices (Inglehard \& Baker, 2000).

One of the most problematic areas, which has aroused due to the practice of disputed customary laws is undefined status of women. The treatment of society towards women and in granting them rights is a subject of debate since decades. Historically, women are always kept in shades and their decisions are never valued. Violence against women was always symbolized as the act of dominant people. It affects women from all kinds of backgrounds. This invasive issue continues to increase the number of victims, who, due to the subject of fear and social pressure, always kept themselves quiet. Sometimes, women are attacked by strangers, but most often they are hurt by people who are close to them like friends, close relatives and family members, who can give dreadful physical and emotional pain (https://www.womenshealth.gov/violence-against-women/).

Women in the Western as well as in the Muslim countries are always prone to inhumane acts and punishments. Out of the various forms of domestic violence which is taking place across the world, honor killing is at the top of the list.

It is defined as a murder, particularly of a woman, who is involved in immoral act, and dishonor the status of a family through unaccepted acts and deeds (Roberts, Campbell and Lloyd, 2013). This unlawful practice (Habib et al, 2013) is mostly attached to females, where the family members kill the victim over unethical charges (Haviland et al, 2013). There is least involvement of law enforcement agencies to look into 
this matter, as these activities take place under the head of the family or the village, and bounded by customary laws.

There are various reasons for honor killing such as extra marital affairs, refusing family decision and act against it, raising voice against cultural traditions. The most important factors attached to the act of honor killing is either psychological or due to socio-cultural barriers. In some cases, greed over the issue of inheritance and family/tribal rivalry also led people to perform honor crimes (Joseph and Nagmabadi, 2003).

The origin of honor killing dated back to the time of Roman Empire, when they were ignorant and had right to murder unmarried daughter. In Europe, the practice of honor killing started during medieval period. In the Arab countries, brutal murder of women was common during early days of ignorance. In Pakistan, it is believed that the Arab settlers brought the tradition of burying girl child (Shirkat Gah, 2003, Goldstein, 2002 and Brundage, 1987).

The issues related to honor killing is observed in the western countries in the forms of force marriages, acid burning, domestic violence, etc (Pope, 2012). According to the report of the United Nations (Chesler, 2009), the issue of honor killing is rising day by day which show that people are move influenced by the customary laws than the national and International laws set by the law bodies. One of such examples is quoted from the report of Germany, which declares that over the past decade, the number of cases of honor killing has increased (Oberwittler \& Kasselt, 2010). Another study proves the presence of honor killing cases in the England. The global statistics also highlight issue of honor killing in Turkey, where high rate of women accidents and suicides are suspected to have cross link with honor killing.

The subject matter of honor killing is also very common among Asian countries (Haybhay, S., Patwe, D., \& Jawale, 2013) and takes the form of murder, rape, etc. Most of the cases of honor killing are reported in the Middle East, India and Pakistan. The research also shares that honor killing is taking place in the west due to migration (Purcell-Riederer, 2013) from the Asian countries, however, no evidence exist in this regard.

One of the researches quoted severe cases of criminal acts against women in the Arab countries, particularly Middle East and Egypt over the issue of veil and interaction with a man outside family (Sorenson, 2013). Another research quotes example of honor killing in Iran, Jordan and Iraq due to weak penalties (Kinnear, 2011).

Through the socio-religious perspectives, it is confirmed that honor killing is not the product of religion. All the religions have given equal status to women and disapprove honor killing by any mean (Hussain, 2006), however other factors promote such acts.

The historical evidences during the pre-Islamic era show traces of honor killing due to weak status of women (Elkayam, 2009). Islam has always supported women and rescued them from oppressions. Islam has also guided Muslims to give equal status to women. Our beloved Holy Prophet (PBUH) has also given respect to women and also guided Muslims to give honor to them in order to save themselves from the fire of hell (Moghissi, 2005).

Family is highly regarded as the promoter of values in the Islamic tradition. It is believed that honor killing mostly take place in the Asian countries in the name of the honor of family.

In Pakistan, honor killing is also called Karo Kari. This compound word is used as a substitute of adultery. Any one, who is found guilty is termed as either Karo or Kari and killed by the family members to restore their honor (Roberts et al., 2013).

It is one of the forms of gender related violence, which is very common in Pakistan. It is a general debate that men and women in Pakistan have equal access to their status, yet male is the dominant figure. The cultural reality of Pakistan is exposed to the world through the act of ignorance as according to the official statistics of the International organization, around one thousand women are killed each year in this male dominant society (Daily Times, 2014) over the issue of honor killing. The research of Human Rights Commission estimated nine hundred murders in the name of honor in the year 2012 (HRCP, 2013).

A pilot study was conducted by one of the renowned local NGO which disclosed the practice of honor killing in Pakistan due to weak governance, social \& cultural barriers, religious and historical factors and dominant status of men in Pakistan (Jafri, 2008). The report of one of the human rights NGO in Pakistan also endorsed rising cases of honor killing in Pakistan, where dozens were killed over the issue of marriage and extra marital affair, while the other fell prey due to various other factors (The News, 2013). 
According to the report of one of the newspapers, more than five hundred women are killed each year and since many cases are unreported, it is predicted that more cases of honor killing exist in all the provinces of Pakistan. It is also disclosed that most of the killing take place due to extramarital relations in Pakistan (The Tribune, 2014). The other reasons include committing adultery, seeking divorce, taunting, settling debts etc (Shah, 2007).

Honor killing is a part of tribal custom. Much of such cases take place in the rural areas of Pakistan. The most affected area from this traditional custom is the rural areas of Sindh (Patel and Gadit, 2008). One of the recent incidents was reported, where two girls in Shikarpur were killed because they desired to marry men of their choices (The News, 2014). Another case, where father openly fire on the girl over the suspicious character of his daughter. It shows that traditional and customary laws have dominated thinking over critical thinking and righteous decisions (Pakistan Today, 2013). Cases of few women, who were buried alive in Pakistan in the name of honor killing was highlighted by Khalil (2010) who said that the life and liberty of female in Pakistan is as per societal norms. Several women were killed because of cultural barriers and political involvement in manipulating the issue. The tagline right to live is mainly controlled by the family head, whereas the ruling elite are imposing customary laws by breaching the state laws.

Number of instruments, laws and treaties are passed to address the issue related to women. On international platform, no law has ever been made to address honor killing, in particular. Indirectly, few of the laws include Convention on the Elimination of All Forms of Discrimination against Women, International Covenant on Civil and Political Rights, Working towards the Elimination of Crimes against Women Committed in the Name of Honour, Declaration on the Elimination of Violence against Women and Declaration of Basic Principles of Justice for Victims of Crime and Abuse of Power. In Pakistan, the Hudood Ordinance, Qisas and Diyat Ordinance are present to relate this issue in the light of law.

The formal law related to honor killing was passed in 2004 to take action against killing over customary practices. The punishment defined in the law is death or lifetime imprisonment (Pakistani Law Firm, n.d.). One of the newspaper said that although national law is available, yet people are not aware about it due to lack of dissemination of knowledge about this law (Express Tribune, 2012). One of the historical researches in Pakistan also disclosed that honor killing in Pakistan is highly practiced yet the culprits are freed due to lack of functionality of laws in Pakistan (Wasti, 2010).

In Pakistan, although few legal amendments have taken place and several judiciary inquiries also took place over honor issues, yet the ground reality portrays women as the subject of violence due to powerful domination of Jirga system and elite class. The law enforcement agencies are quiet and helpless because of weak vision and mission towards the rights of women in Pakistan (Jafri, 2008, Lari, 2011). The research study disclosed that traditional laws are not the sole responsible factors for honor killing in Pakistan. The feudal lord culture, male dominant society and illiteracy equally draft narrow mindset (Bhanbhro et al., 2013).

It is believed that education plays important role in changing the mindset of people. From the global perspectives, several researches were conducted to find the attitude of people towards honor killing. A research study was conducted to find, how education bring traditional changes in society. The results share that issue of gender inequality and higher education do not significantly change the mindset of the students, due to which, issue of honor killing exist (Miller, 2009). Another research study took place in Jordan which shows that the rights of women are more supported by the educated people (Eisner and Ghuneim, 2013).

A survey took place in one of the cities of Pakistan to find the attitude of either gender towards honor killing. Majority of the men and women supported the practice of honor killing, if women is found guilty (Shaikh, et al 2010). This research shows that culture and traditional mind-set still exist in Pakistan.

\section{Conclusion}

Zvinkliene (2008) said that from the sociological point of view, modern society must grow in today's society. The cultural traditional mindset still dishonor women because it is in human nature to maintain status and if it is disturbed or dishonored, people can act brutally by dishonoring others, which is completely wrong act. The researcher concludes that unless women are aware about their rights, unless laws become functional, it is impossible to bring changes in society. Government must draft action plan and bring positive changes in society by drafting strict laws over the issue of honor killing. NGOs must also emphasize government to ban unethical practices from society. 


\section{References}

[1]. Bhanbhro, S., Wassan, M., Shah, M., Talpur, M., and Wassan, A. (2013). Karo Kari: the murder of honour in Sindh Pakistan: an ethnographic study. International Journal of Asian Social Science, 3 (7). 1467-1484.

[2]. Brundage, J. (1987). Law, Sex and Christian Society in Medieval Europe, Chicago: University of Chicago Press.

[3]. Chesler, P. (2009). Are Honor Killings Simply Domestic Violence? The Middle East Quarterly, 16(2), 61-69

[4]. Daily Times. (2014). Please Stop Honor Killings. Retrieved http://www.dailytimes.com.pk/opinion/29-Mar-2014/please-stophonour-killings

[5]. Eisner, M., and Ghuneim, L. (2013). Honor Killing Amongst Adolescents in Amman, Jordan. Aggressive Behavior, 39 , $405-417$.

[6]. Elkayam A. (2009). The Quran and Biblical Origins. Xlibris Corporation.

[7]. Goldstein, M.A. (2002). The biological roots of heat-of-passion crimes and honour killings. Politics and the Life Sciences $21,2$.

[8]. Habib, H., Asad, U., \& Muhammad, I. (2013). Honor Killing: Its Causes and Socio-Legal Controlling Mechanisms. LAP Lambert Academic Publishing

[9]. Haviland, W., Prins, H., McBride, B., and Walrath, D. (2013). Cultural Anthropology: The Human Challenge. Cengage Learning

[10]. Haybhay, S., Patwe, D., and Jawale, P. (2013). Honor killing: Killing the honour of humanity? SASCV 2013 Proceedings

[11]. HRCP. (2013). State of human rights in 2012. Retrieved from http://hrcp-web.org/hrcpweb/wp-content/pdf/AR2012.pdf

[12]. Hussain, M. (2006). Take my Riches, Give me Justice: A Contextual Analysis of Pakistan's Honor Crimes Legislation. Harvard Journal of Law \& Gender.

[13]. Inglehard, R., \& Baker, W.E. (2000). Modernization, Cultural Change and the Persistence of Traditional Values. American Sociological Review, 65, 19-51.

[14]. Jafri, A. (2008). Honor Killing: Dilemma, Ritual, Understanding. Oxford University Press.

[15]. Joseph, S., \& Nagmabadi, A. (2003). Encyclopedia of Women \& Islamic Cultures: Family, Body, Sexuality and Health. Volume 3. BRILL.

[16]. Khalil, N.A. (2010). Honor Killing in Pakistan: The Case of 5 Women Buried AliveO Political manipulation in human rights Violation. Retrieved from http://www.humiliationstudies.org/documents/AkbarHonorKillinginPakistan.pdf

[17]. Kinnear, K.L. (2011). Women in Developing Countires: A Reference Handbook. ABC-CLIO

[18]. Lari. M. (2011). A Pilot Study on Honor Killings in Pakistan and Compliance of Law. Aurat Foundation.

[19]. Miller, A. (2009). A Sociological Analysis of Crimes of Honor: Examining the Effects of Higher Education on the Concepts of Honor and Notions of Gender Equality in Jordan. Independent Study Project (ISP) Collection. Paper 750.

[20]. Moghissi, H. (2005). Women and Islam: Images and Realities. Taylor \& Francis

[21]. Oberwittler, D., \& Kasselt, J. (2010). Honor Killings in Germany, 1996-2005, A Study based on Prosecution Files. Max-PlanckInstitute.

[22]. Pakistan Today. (2013). Honour Killing : Girl slayed in Dera Murad Jamali. Retrieved from www.pakistantoday.com.pk/2013/12/11/national/honour-killing-girl-slayed-in-dera-murad-jamali/

[23]. Pakistani Law Firm. (n.d.). Laws against Honour Killing...Karokari in Pakistan. Retrieved from http://pakistanilaws.wordpress.com/2012/04/23/laws-against-honour-killing-i-e-karokari-in-pakistan/

[24]. Patel, S., and Gadit, A.M. (2008). Karo-Kari: A Form of Honour Killing in Pakistan. Transcultural Psychiatry, 45(4), 683-694.

[25]. Pope, N. (2012). Honor Killings in the Twenty-First Century. Palgrave Macmillan.

[26]. Purcell-Riederer, B. (2013). Honour Killings in Europe: Different approaches; a comparison between responses of honour killings in England and Germany. GRIN Verlag.

[27]. Roberts, K., Campbell, G., and Lloyd, G (2013). Honor-Based Violence: Policing and Prevention. CRC Press.

[28]. Shah, N. (2007). Making of crime, customs and culture: The case of karo kari killings of upper Sindh. Scratching the surface: Democracy, traditions, gender. Lahore:Heinrich Böll Foundation

[29]. Shaikh, M.A., Shaikh, I, Kamal, A and Masood, S. (2010). Attitudes about Honor Killing among Men and Women- Perspective from Islamabad. Journal of Ayub Medical College Abbotabad, 22(3), 38-41

[30]. Shirkat Gah. (2003). Women Living Under Muslim Laws, Karo-Kari, TorTora, Siyahkari, Kala Kali: There is no honour in killing. National Seminar Report, November 2001.

[31]. Sorenson, D.S. (2013). An Introduction to the Modern Middle East: History, Religion, Political Economy, Politics. Perseus Books Group.

[32]. Swadzba, U. (2011). The Impact of Globalization on the Traditional Value System. University of Ostrava.

[33]. The News. (2014). Karo-kari devour two more girls in Shikarpur. Retrieved from http://www.thenews.com.pk/article-141424-Karokari-devour-two-more-girls-in-Shikarpur

[34]. The News. (2013). HRCP says 'honour killings' on the rise in Pakistan. The News.

[35]. The Tribune. (2014). Crimes against women: 'There are more honour killings than we know. The Tribune.

[36]. Violence against Women. Retrieved from https://www.womenshealth.gov/violence-against-women/

[37]. Express Tribune. (2012). Law against 'honour killing': When the enforcers don't get it, how will the victims? Express Tribune.

[38]. Wasti, T. (2010). The Law on Honour Killing: A British Innovation in the Criminal Law of the Indian Subcontinent and its Subsequent Metamorphosis under Pakistan Penal Code. South Asian Studies, 25(2).

[39]. Zvinkliene, A. (2008) Honour Killings' in Modern Societies: A Sociological Perspective. Islam and Civilizational Renewal 1(3). 